\title{
Taxonomy, distribution and population structure of invasive Corbiculidae (Mollusca, Bivalvia) in the Suquía River basin, Córdoba, Argentina
}

\author{
Paola B. Reyna ${ }^{1}$, Ariana G. Morán ${ }^{1} \&$ Marcos Tatián $^{1,2}$
}

1. Ecología Marina, Facultad de Ciencias Exactas, Físicas y Naturales, Universidad Nacional de Córdoba (UNC). Av. Vélez Sarsfield 299, Córdoba, Argentina. (reynasandrip@gmail.com)

2. Instituto de Diversidad y Ecología Animal (CONICET/UNC), and Facultad de Ciencias Exactas, Físicas y Naturales, Universidad Nacional de Córdoba. Av. Vélez Sarsfield 299, (5000) Córdoba, Argentina.

\begin{abstract}
Invasive species are one of the most significant causes of biodiversity loss and changes in ecosystem services, which underlines the importance of their detection and their study. The Asian clams (Corbiculidae) are invasive organisms that accidentally entered the La Plata River, Argentina, presumably in the 1960s. The objectives of the present study were to identify the corbiculid species and to determine their distribution at several locations along the Suquía River basin, an extended area in central Argentina. In addition, population structure was evaluated monthly during one year, at a site in the city of Córdoba that is characterized by high human influence. The presence of Corbicula fluminea (Müller, 1774) and Corbicula largillierti (Philippi, 1844) in the Suquía River basin is reported for the first time. The former species was found only in a lentic environment (San Roque reservoir), while the latter was also found along the tributary rivers and brooks of the basin. Corbicula largillierti showed variations in average density between the different sites and also in biomass and size classes throughout the study period at the site at Córdoba city. The relative composition of the sediments, flow fluctuation and human pollution may be responsible for the observed differences.
\end{abstract}

KEYWORDS. Corbicula largillierti, Corbicula fluminea, exotic species, colonization.

RESUMEN. Taxonomía, distribución y estructura poblacional de Corbiculidae (Mollusca, Bivalvia) invasores en la cuenca del Río Suquía, Córdoba, Argentina. Las especies invasoras son una de las causas más importantes de la pérdida de biodiversidad y de las alteraciones que se producen en los servicios ecosistémicos; en ello reside la importancia de la detección de estas especies y su estudio. Las almejas asiáticas (Corbiculidae) son organismos invasores que ingresaron accidentalmente en el Río de La Plata, Argentina, presuntamente en la década de los 1960'. Los objetivos del presente trabajo fueron identificar las especies de corbicúlidos y determinar su distribución en distintas localidades a lo largo de la cuenca del Río Suquía, un área extensa localizada en el centro de Argentina. Asimismo, la estructura poblacional fue evaluada mensualmente durante el periodo de un año, en un sitio de la ciudad de Córdoba caracterizado por una alta influencia humana. Se reporta por primera vez la presencia de Corbicula fluminea (Müller, 1774) y Corbicula largillierti (Philippi, 1844) en la cuenca del Rio Suquía. La primera sólo se encontró en un ambiente léntico (embalse San Roque), mientras que la segunda especie también se encontró a lo largo de los afluentes y arroyos de la cuenca. Corbicula largillierti mostró una variación en la densidad media, considerando los diferentes sitios; asimismo en la biomasa y las clases de tamaño en un mismo sitio, durante el período de estudio. La composición relativa de los sedimentos, la fluctuación del caudal y la contaminación humana podrían ser las responsables de las diferencias observadas.

PALABRAS-CLAVE. Corbicula largillierti; Corbicula fluminea; especies exóticas; colonización.

Together with habitat disturbance, climate change, overexploitation, and contamination, invasions by exotic species are one of the most important causes of biodiversity loss in different environments worldwide (AgIUs, 2007). Freshwater systems are particularly subject to invasion by exotic invertebrate species, which use water current for dispersion throughout these systems. Among these invertebrates, mollusks are a group with high potential for invasion: they can filter out phytoplankton and seston, graze on periphyton or browse on vascular plants (FrANÇA et al., 2007; STRAYER, 2010). These species can develop massive populations in all kinds of fresh waters, consuming algae stock and substantially affecting the amount and composition of primary producers. Interactions radiating out from the primary producers can affect nearly every part of the ecosystem (STRAYER, 2010). In recent decades, two species of freshwater bivalves have been reported as invasive in inland waters of South America: the golden mussel, Limnoperna fortunei (Dunker, 1857), and the Asian clam, Corbicula fluminea (Müller, 1774).

In the case of bivalves, shells can reach high morphological plasticity due to the different environments and ecological conditions in which they live (BAKER et al., 2003). This phenotypic plasticity was reported in the species of the genus Corbicula (RENARD et al., 2000; PARK et al., 2002; PfENNINGER et al., 2002; LEE et al., 2005). For that reason, the systematics of Corbicula is uncertain and especially the study of lineages in the New World, where three morphotypes have been distinguished. These are forms $\mathrm{A}$ and $\mathrm{B}$ (BRITTON \& MORTON, 1986), present throughout the continent, and form C (ITUARTE, 1994), only present in South America and known as $C$. largillierti. According to LEE et al. (2005), there are hybrids between the different forms. PFEnNINGER et al. (2002) proposed that different lineages of Corbicula may be an initial state of a group of species rather than a defined species. MORTON (1986) considered that the observed variability could correspond to a single species.

Since the beginning of the twentieth century, the worldwide distribution of the genus Corbicula has extended from its native habitat in Asia, Africa and Australia to the rest of the world (ArAujo et al., 1993; Ituarte, 1994; McMahon, 2000). These bivalves had colonized South America by early 1960s, when the bivalve arrived in Argentina and Brazil, through the La Plata River (Veitenheimer-Mendes, 1981; 
ITUARTE, 1994) and subsequently spread into Venezuela (McMahon, 2000), the northern part of the Pantanal in Southwest Brazil (CAllil \& Mansur, 2002) and lower areas of the Amazon River basin (BEASLEY et al., 2003) among other areas. Nowadays, they are one of the dominant freshwater benthic macrofauna in an area extending from Lake Superior in North America (WARD \& Hodgson, 1997) to Patagonia in South America (CAZZAniga, 1997).

In Argentina, Corbicula extends along the La Plata River basin and has also been reported in scattered locations throughout the provinces of Buenos Aires, Catamarca (Rumi et al., 2007) and Río Negro, and on the shores of the rivers Colorado and Negro (CAZZANigA, 1997; Cazzaniga \& Perez, 1999). In central Argentina (Córdoba province), it is distributed in the river Carcarañá (DARRIGRAN \& DAMBoreneA, 2005) and Rio Tercero reservoir (M. Tatián, pers. obs.), which are part of the La Plata River basin. Until now, they have not been reported in central Argentina in rivers and brooks that do not belong to that basin, as is the case of the Suquía River basin.

Clam density varies with particle size, and they have a strong preference for sandy substrates (FAST, 1971; Cherry et al., 1980). However, C. fluminea can colonize a wide variety of substrates: rocks, gravel, boulders, sand and clay (HoRne \& McInTOSH, 1979; BELANGER et al., 1985). DARRIGRAN (1992a) recorded that, in environments with a substrate composed of silty sediment, $C$. largillierti dominates over $C$. fluminea.

Other parameters, such as fluctuation in water level and contamination, can also determine the presence and density of these animals and produce alterations in their population structure (DARRIGRAN \& DAMBORENEA, 2005; De La Hoz AristizÁBal, 2008). Given the taxonomic uncertainties in the genus Corbicula and the particular characteristics of the Suquía River basin, i.e. its diverse substrate types, fluctuations in the flow regime and the impact of human activities, the presence, distribution and density of Asian clams will vary throughout this extensive area.

With the aim of making a first diagnosis of the status of the invasion of these bivalves in the Suquía River basin, species identification, distribution and density were studied at different localities. Variations in population structure (density, biomass, spatial distribution and size-classes) were also analyzed at one site in Córdoba city, a densely populated area characterized by human activities.

\section{MATERIALS AND METHODS}

Study area. The Suquía River basin (Fig. 1), located in Córdoba province (Argentina), is an area of special interest, because the river flows into Mar Chiquita, one of the largest salt lakes in the world. Together with the Dulce River wetlands, these have been designated as Ramsar sites (The Ramsar Convention on Wetlands). The Suquía River is a tributary of the rivers Cosquín and San Antonio and the brooks Las Mojarras and Los Chorrillos; all of these flow into the San Roque reservoir, where the tourist city of Carlos Paz $(81,000$ inhabitants) is located. This dam regulates the flow of the Suquía River northeast, as this is the main source

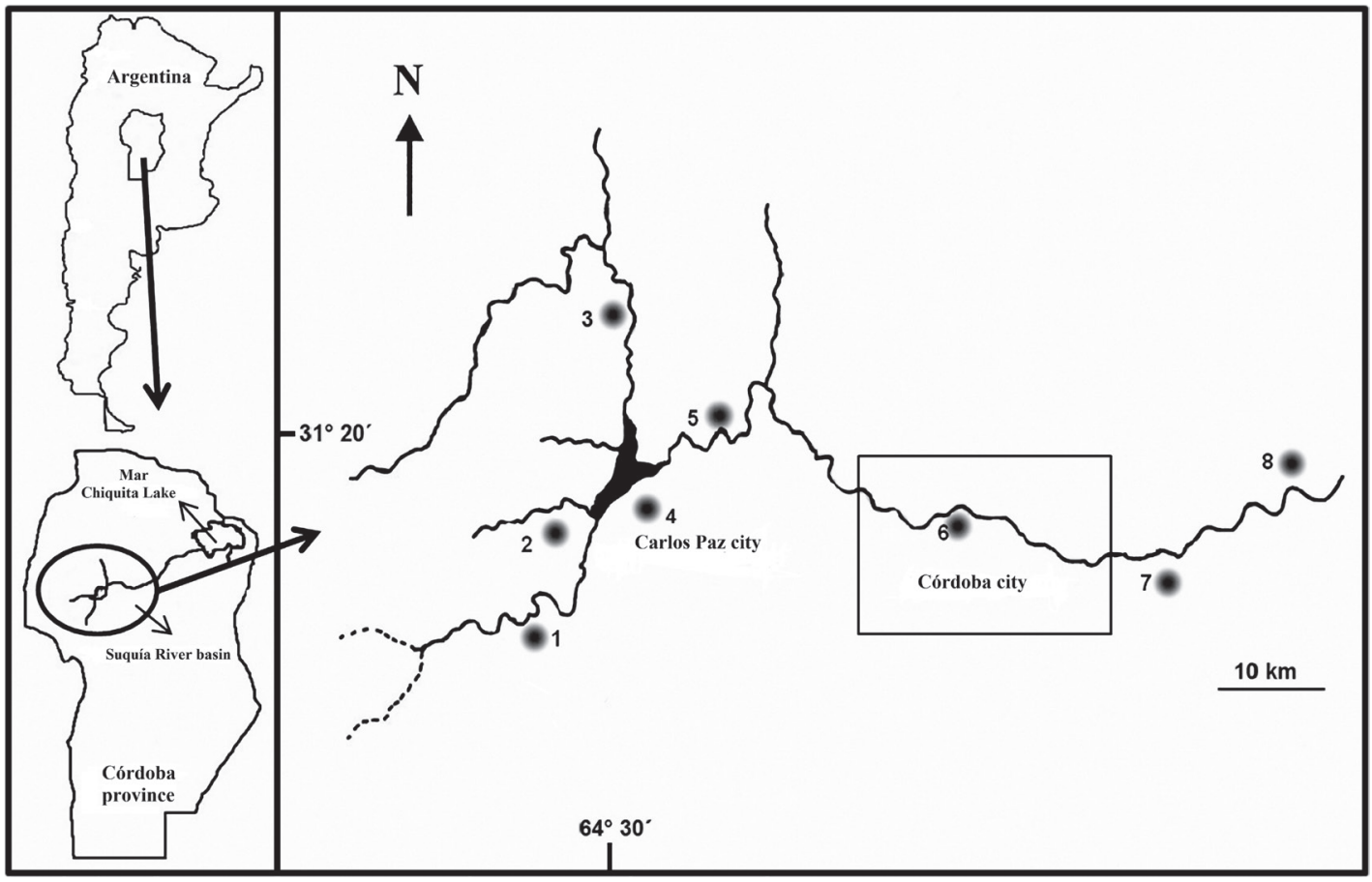

Fig. 1. Map of the Suquía River basin, Argentina: (1) Icho Cruz (San Antonio River); (2) Cabalango (Los Chorrillos Brook); (3) Bialet Massé (Cosquín River); (4) Carlos Paz city (San Roque reservoir); (5) Casabamba (Suquía River); (6) Eliseo Cantón Bridge, Córdoba city (Suquía River); (7) Malvinas Argentinas (Suquía River); (8) Río Primero (Suquía River). Modified from Hued \& Bistoni (2005). 
of drinking water for the city of Córdoba (1.3 million inhabitants), located $35 \mathrm{~km}$ downstream.

The Suquía River basin is a semiarid region, with mean annual precipitation ranging from 700 to 900 $\mathrm{mm}$. The pluvial regime is characterized by biannual discontinuity. The wet season occurs between October and March with rainfall concentration in January and February. The Suquía River has a high-flow period from December to April, with an estimated flow of $15 \mathrm{~m}^{3} / \mathrm{s}$, while during the dry season, from May to November, its estimated flow is $10 \mathrm{~m}^{3} / \mathrm{s}$ with a minimum in June of $5 \mathrm{~m}^{3} / \mathrm{s}$ (VÁzQueZ et al., 1979).

The headwaters of the Suquía River basin are characterized by rocky substrates, high slopes and fast flowing waters with scarce macrophyte cover. The middle section of the basin presents a gravel substrate alternating with sandy substrate. Downstream of Córdoba city, there is a high proportion of fine substrates, waters flow more slowly and the river becomes wider (Hued \& Bistoni, 2005).

Chemical analyses of the middle-lower Suquía River basin show a water-quality degradation gradient. The middle section of the basin is reported to have significant levels of water contamination (WUNDERLIN et al., 2001; NIMPTSCH et al., 2005; CONTARDO-JARA et al., 2009; MAGGioni et al., 2012). High levels of pollutants (ammonium, nitrate, calcium, coliforms) and low dissolved oxygen values were measured previously in the localities of Malvinas Argentinas and Río Primero. Contamination increases downstream of the city of Córdoba from the dumping of raw sewage from the city treatment plant (WunderLIN et al., 2001; HUED \& Bistoni, 2005; MONFERRÁN et al., 2011).

Sampling design. In order to assess the presence and density of corbiculids along the Suquía River basin, samplings were performed at eight sites: Icho Cruz, Cabalango, Bialet Massé, Carlos Paz city, Casabamba, Eliseo Cantón Bridge (Córdoba city), Malvinas Argentinas, and Río Primero (Fig. 1). One of these sites (Eliseo Cantón Bridge) corresponds to a densely populated area of Córdoba city: at that site, sampling was performed monthly during an entire year (from May 2009 to April 2010).

Living animals and shells were collected on sandy bottoms along one transect $(10 \mathrm{~m})$ parallel to the river bank. Collection of animals buried in the surface sediment (up to $10 \mathrm{~cm}$ deep) was made in 10 random replicates of an area of $0.05 \mathrm{~m}^{2}$ estimated by a surface sampler (ItUARTE, 1981). The sediment was sieved through two meshes (5 $\mathrm{mm}$ and $1 \mathrm{~mm}$ respectively) to collect different-sized specimens. Additional surface sediment samples were collected by a cylinder $\left(0.001 \mathrm{~m}^{2}\right)$ and not sieved, to determine the presence and abundance of smaller size individuals under stereomicroscope.

Variations in range of environmental parameters such as water temperature, dissolved oxygen and $\mathrm{pH}$ were measured at Eliseo Cantón Bridge during the whole year.
Taxonomy. The following characters were evaluated in order to identify the specimens at species level: pigmentation of the area around siphons, disposition of siphonal tentacles, gill size (MARTINs et al., 2006), shell shape, disposition and number of shell ribs (Ituarte, 1994; Mansur \& Pereira, 2006). Different shell measurements such as length (anteroposterior distance; Ls), height (distance from the umbo to the ventral margin) and width (distance across the shell) were made with a digital caliper $(0.01 \mathrm{~mm}$ accuracy). Rib numbers were counted along $1 \mathrm{~cm}$ of the outer surface of the shell, considering the dorsoventral line. The differences were tested by univariate analysis (ANOVA) with $\log (\mathrm{x})$ transformations after testing the variance homogeneity (Cochran's C test). Then an a posteriori test (LSD) was applied with a significance level of 5\%. Several specimens were fixed in 70\% ethanol and deposited in the Museo de Zoología, Universidad Nacional de Córdoba, Argentina.

Population structure. The density was estimated as individuals per square meter (ind. $/ \mathrm{m}^{2}$ ). The shells were removed before mass determinations $\left(60^{\circ} \mathrm{C}, 24 \mathrm{~h}\right)$. The biomass was expressed as milligrams of dry weight per square meter $\left(\mathrm{mg} \mathrm{DW} / \mathrm{m}^{2}\right)$. Dispersion index (variance/ mean ratio) and Morisita's Index (MoRIsITA, 1962) were used to determine the spatial distribution pattern. These indices take different values: 1 (populations randomly distributed); $<1$ (populations prone to uniformity); $>1$ (aggregate populations) (KREBS, 1999).

The structure of the population was analyzed according the following size-classes (shell length): small individuals (1-10 mm), medium individuals $(11-20 \mathrm{~mm})$ and large individuals $(21-30 \mathrm{~mm})$. The size distribution was plotted in a frequency histogram. Mean values and dispersion estimations for length, height and width of the shells were also plotted.

Statistical analysis. The density differences between the sampling sites were analyzed by univariate analysis (ANOVA) with $\log (\mathrm{x})$ transformations after testing the variance homogeneity (Cochran's C test), and a posteriori test (LSD) was applied with a significance level of $5 \%$. The monthly differences in density were analyzed using the nonparametric Kruskal-Wallis test complemented with an LSD test. The dispersion index was analyzed by Chi-square test $\left(\chi^{2}\right)$ with $n-1$ degree of freedom and an alpha of 0.05 .

\section{RESULTS}

Two species, Corbicula largillierti and $C$. fluminea (Fig. 2), were identified in the Suquía River basin. The variability of the characters used to identify the specimens at species level is listed in Tab. I. The number of ribs present on the outer surface of the shell was significantly different between the two species (ANOVA $\mathrm{F}=166.2 ; \mathrm{p}<0.05$ ).

Corbicula largillierti was found in most of the 


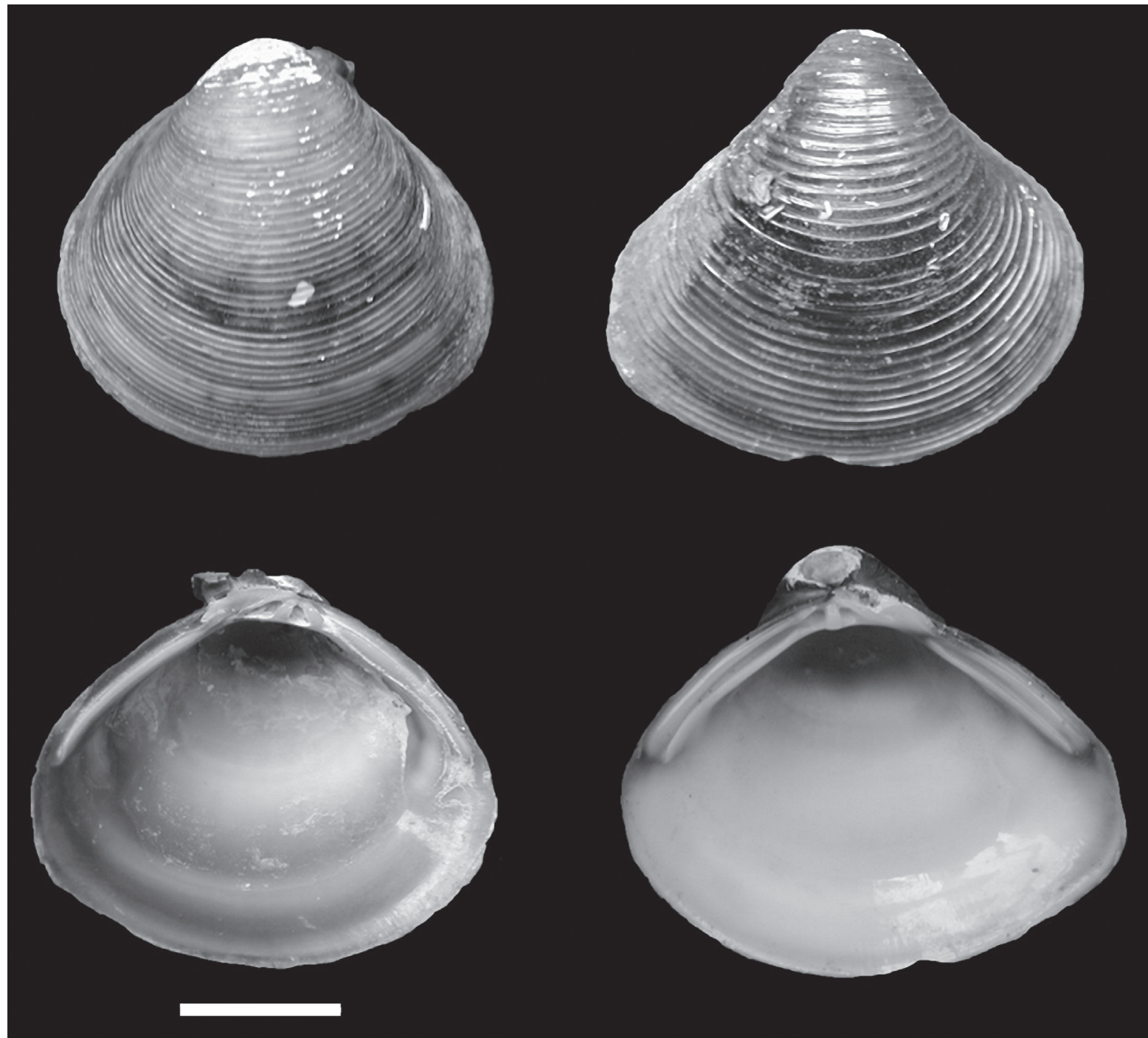

Fig. 2. External and internal view of Corbicula largillierti (Philippi, 1844) (left) and C. fluminea (Müller, 1774) (right) shells. Scale $1 \mathrm{~cm}$.

sites sampled. However, it was not present downstream of Córdoba city, in the sampling localities of Malvinas Argentinas and Río Primero. In the upper basin, at Bialet Massé and Casabamba, the species had a density of 74 \pm 156 and $112 \pm 95.5$ ind. $/ \mathrm{m}^{2}$ respectively; no living individuals were found at Icho Cruz, Cabalango or
Carlos Paz city, where only empty shells were found. Neither shells nor living animals of $C$. fluminea were found in lotic systems. This species was restricted to Carlos Paz city with a density of $4 \pm 8$ ind. $/ \mathrm{m}^{2}$.

The dispersion index $(8.16 \mathrm{p}<0.01)$ and Morisita's index (1.49) suggested an aggregated spatial distribution

Tab. I. Variability found in the characters used to identify Corbicula fluminea (Müller, 1774) and C. largillierti (Philippi, 1844).

\begin{tabular}{lll}
\hline Character & Corbicula largillierti & Corbicula fluminea \\
\hline $\begin{array}{l}\text { Shell color } \\
\text { Outer side }\end{array}$ & Brown & Olive green /ochre/ brown \\
Inner side & Purple/violet & Ivory \\
Ribs & Concentric and low & Concentric and elevated \\
Number of ribs & $14-23$ ribs.cm ${ }^{-1}$ & 8-11 ribs.cm ${ }^{-1}$ \\
Shell posterior margin & Slightly pronounced & Pronounced \\
Umbo & Flat & Inflated \\
Length of the demibranchs & $\begin{array}{l}\text { Outer demibranch shorter than inner } \\
\text { demibranch }\end{array}$ & Outer and inner demibranchs of similar size; or the \\
Siphons & former reaching the half size of the latter \\
Disposition of the tentacles & Inhalant siphon: no rows, multiple tentacles & Inhalant siphon: two rows of tentacles \\
Pigmentation & Weak pigmentation around the exhalant & Strong pigmentation surrounding both siphons \\
\hline
\end{tabular}


pattern in Corbicula largillierti. The low density at Carlos Paz city did not allow evaluation of the spatial distribution of $C$. fluminea at this site.

There were significant differences in the density of C. largillierti between the different sampling sites along the basin (ANOVA F=9.51; $\mathrm{p}<0.01$ ). At Eliseo Cantón Bridge, the average density year-round was 302 ind. $/ \mathrm{m}^{-2}$; the minimum was registered in January 2010 (6 ind. $\left./ \mathrm{m}^{-2}\right)$ and the maximum in July 2009 (674 ind. $/ \mathrm{m}^{-2}$ ). Monthly variations throughout the period resulted in differences between May, July-October 2009 in relation to the period from November 2009 to April 2010 (Tab. II). The mean biomass reached $9.41 \mathrm{mg} \mathrm{DW} / \mathrm{m}^{2}$ throughout the study period.

The range of shell length (Ls) for $C$. largillierti at Eliseo Cantón Bridge was 6.2-26 mm, with a higher frequency of individuals between 15 and $21 \mathrm{~mm}$ Ls (Fig. 3 ). The values of shell length, width and height (mean \pm standard deviation) were $17.8 \pm 12.82 \mathrm{~mm}, 9.26 \pm 3.33$ and $15.44 \pm 2.56$ respectively $(\mathrm{N}=1,904)$. Small-sized individuals (up to $10 \mathrm{~mm}$ ) decreased from July onwards; individuals of intermediate size (particularly between 16 and $20 \mathrm{~mm}$ ) were found throughout the sampling period. Large-sized individuals (greater than $21 \mathrm{~mm}$ ) were found from May to November.

The average, standard deviation and range of water parameters measured at Eliseo Cantón Bridge were: temperature $\left(20.9 \pm 6.6^{\circ} \mathrm{C} ; 6-30^{\circ} \mathrm{C}\right)$; dissolved oxygen $\left(7.7 \pm 0.7 ; 7.08-8.55 \mathrm{mgl}^{-1}\right)$ and $\mathrm{pH}(8 \pm 0.1$; $7.2-8.2)$

\section{DISCUSSION}

Following the analyses of different outer and inner characters suggested by previous authors (ITUARTE, 1994; Lee et al., 2005; Mansur \& Pereira, 2006; Martins et al., 2006), we report the presence of Corbicula largillierti and $C$. fluminea in the Suquía River basin. Among the previously reported characters, rib number was useful to differentiate the two species (Tab. I). The average
Tab. II. Monthly variations in the density (ind. $/ \mathrm{m}^{-2}$ ) of Corbicula largillierti (Philippi, 1844) at Eliseo Cantón Bridge (Córdoba city), Argentina. Different letters mean significant differences (Kruskal-Wallis; $p<0.5$ ).

\begin{tabular}{lcc}
\hline Month/year & $\begin{array}{c}\text { Density } \\
(\text { mean } \pm \text { SD) }\end{array}$ & LSD test \\
\hline May/2009 & $556 \pm 644$ & $\mathrm{bc}$ \\
June/2009 & $280 \pm 220$ & $\mathrm{ab}$ \\
July/2009 & $674 \pm 416$ & $\mathrm{c}$ \\
August/2009 & $500 \pm 308$ & $\mathrm{bc}$ \\
September/2009 & $592 \pm 520$ & $\mathrm{c}$ \\
October/2009 & $566 \pm 409$ & $\mathrm{c}$ \\
November/2009 & $78 \pm 103$ & $\mathrm{a}$ \\
December/2009 & $30 \pm 45$ & $\mathrm{a}$ \\
January/2010 & $6 \pm 19$ & $\mathrm{a}$ \\
February/2010 & $146 \pm 107$ & $\mathrm{a}$ \\
March/2010 & $100 \pm 83$ & $\mathrm{a}$ \\
April/2010 & $106 \pm 71$ & $\mathrm{a}$ \\
\hline
\end{tabular}

values obtained in both cases differed significantly. Nevertheless, given possible hybridization and high variability resulting from environmental factors, additional studies, such as molecular and geometric morphometry (Sousa et al., 2007), could be useful to measure shell plasticity and population differences.

In the Suquía River basin, C. fluminea is restricted to a lentic environment (San Roque reservoir), apparently coexisting with $C$. largillierti, although only empty shells of this species have been found in this site. In rivers and brooks, the presence of only $C$. largillierti was detected. In localities such as Cabalango and Icho Cruz, the presence of only empty shells suggested the colonization of these sites (living C. largillierti individuals had been collected in Cabalango previously, M. Tatián, pers. obs.). The absence of living specimens could be due to the dynamics of these rivers, the flow of which depends on rainfall that mostly occurs during the southern summer (from November to March). The reduction of river flow during the dry season, in winter, exposes the sandbanks, where the bivalves are often buried, causing the death of animals. DARRIGRAN (1992a) found Corbicula mainly in lentic environments, with $C$. fluminea restricted to shallow, well-oxygenated coastal waters. Besides,

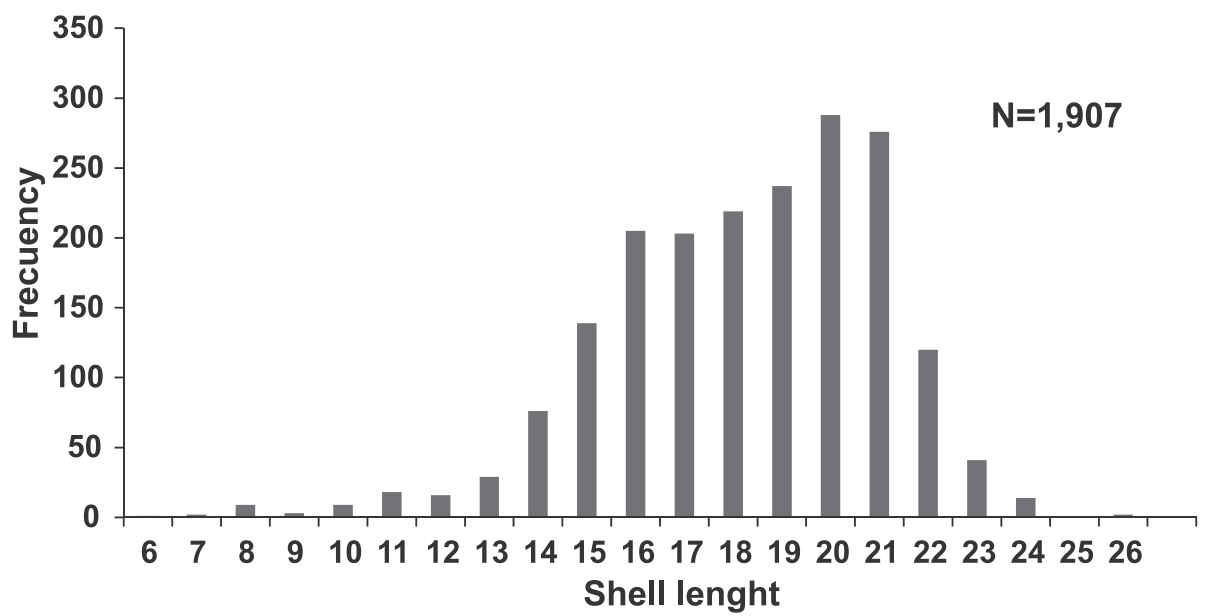

Fig. 3. Frequency histogram for the shell lengths of Corbicula largillierti (Philippi, 1844) collected throughout the study period at Eliseo Cantón Bridge (Córdoba city), Argentina. 
abundant populations of $C$. fluminea were detected in the headwaters of micro-basins and rivers with stronger flow (ARoceno et al., 2008). In the present study the distribution of $C$. fluminea, limited in the Suquía River basin to San Roque reservoir, is striking, considering the wide, rapid spread of this species along the La Plata River basin. On the other hand, C. largillierti, which was distributed in the majority of the sampling sites along the Suquía River basin, was restricted to a few sites in the La Plata River basin (DARrigran, 1992b). CASTILlo et al. (2007) observed that $C$. largillierti was better adapted to brook environments. The absence of $C$. lagillierti downstream of Córdoba city in the locality of Malvinas Argentinas could be due to the high contamination and low oxygen levels $\left(5 \pm 2.1 \mathrm{mgl}^{-1}\right)$ detected in that area (WUNDERLIN et al., 2001); these are probable stress conditions that would limit the survival of juvenile and adult bivalves and, therefore, their dispersion from the upper to the lower basin.

The mechanism that enabled the introduction of these bivalves in the Suquía River basin is uncertain, since it is geographically disconnected from the arrival area (La Plata River basin). Accidental introduction through larvae present on the hulls of fishing boats is one of the most probable causes (RoDRIGUES et al., 2007; STRAYER, 2010). Thereafter, expansion would have occurred by natural mechanisms. The natural spread of these species typically occurs during two stages of their development: the veliger and the juvenile forms (DARRIGRAN, 2002). In both cases, dispersion is favored by passive transport by the current, enabling colonization downstream and, in some cases, facilitating the re-establishment of disturbed populations (CounTs, 1986). Dispersion capacity during the adult stage is lower, but may be aided by human activities that promote transportation (DARRIGRAN \& DAMBORENEA, 2005).

At Eliseo Cantón Bridge, successive rises in the river during November and December 2009 and January 2010 also produced movement of the sandbank and a fall in corbiculid density. A previous report mentioned a decrease in the density of $C$. fluminea in environments characterized by high fluctuation and significant drops in the water level: the density of clams increased with a rise in water level (De La Hoz AristizÁbal, 2008). The average density observed at this site $\left(302\right.$ ind. $\left./ \mathrm{m}^{2}\right)$ was similar to the density found in a tributary lentic environment of La Plata River basin (459 ind. $/ \mathrm{m}^{2}$, DARRIGRAN, 1992a), but was considerably less than the mean density of Corbicula found in the La Plata River (2,495 ind./m², DARRIGRAN, 1991).

The estimated dispersion and Morisita's indices suggest an aggregate distribution pattern in C. largillierti. This is a very common pattern in nature (Levin, 1992); the proposed biological mechanisms behind aggregation include antipredator behavior, reproductive advantages and resource utilization (WITTENBERG, 1981).

The most frequent shell-size class $(15-22 \mathrm{~mm})$ of
C. largillierti in the study area indicates the predominance of young adults (1-2 years). The relationship between shell size and age was previously studied by MCMAHON (1983): smaller sizes correspond to younger specimens up to one year, intermediate sizes to adults aged 1-2 years, while large sizes correspond to individuals of 3-4 years. The maximum size found for $C$. largillierti was $26 \mathrm{~mm}$, observed in few specimens, which presumably reach the maximum lifespan (2.5 years) estimated for that species (DARRIGrAN, 1997).

Sampling at Eliseo Cantón Bridge revealed a great number of medium-sized animals all the year-round. The absence of small and large-sized individuals and the high density of medium-sized individuals may be caused by contamination harming the larvae and preventing the growth of individuals (Boltovskoy et al., 1997). This site is in the center of Córdoba city, where the river is flanked on both sides by frequently used highways, and is connected to the city rain water channels as well as illegally introduced garbage and sewage waters (CONTARDO-JARA et al., 2009).

Environmental data collected monthly at this point reflects a wide range of water temperatures. On the other hand, dissolved oxygen and $\mathrm{pH}$ were neither fluctuating nor extremes. According to DARRIGRAN \& Damborenea (2005), C. fluminea tolerates water temperatures in the range of $2-30^{\circ} \mathrm{C}$ without negative effects; dissolved oxygen lower than $3 \mathrm{mgl}^{-1}$ can restrict presence, density and growth. In spite of the absence of young and old specimens, the environmental values registered at Eliseo Cantón Bridge do not seem to be limitative for Corbicula.

The invasion of Corbicula extends to a wider area of central Argentina, including the Segundo River basin (rivers Los Molinos, Anizacate and Xanaes) and Carcarañá River basin (Tercero River reservoir and Ctalamochita River). For unknown reasons, they have not yet colonized the entire area of these basins, such as the rivers that feed Los Molinos reservoir. Given the speed of colonization reported in the La Plata River basin, it is assumed that colonization in the Suquía River basin is recent. Environmental factors, such as water temperature, bottom availability and typology, the dynamics of flow and high levels of contamination, may be preventing wider distribution. In the La Plata River basin, spatial and temporal variations were observed in the area occupied by C. largillierti; the species showed a progressively decreasing distribution range and density, reflecting inter-specific competition with C. fluminea (DARRIGRAN, 1992a). The same may occur in the Suquía River basin. While the distribution of $C$. fluminea is continuously expanding (DARRIGRAN, 2000), that of $C$. largillierti is not well known, hence determination of the actual distribution of these species in the study area is an important step in the knowledge of the invasion processes related to these species. 


\section{REFERENCES}

AgIUS, B. 2007. Spatial and temporal effects of pre-seeding plates with invasive ascidians: growth, recruitment and community composition. Journal of Experimental Marine Biology and Ecology 342:30-39.

Araujo, R.; Moreno, D. \& Ramos, M. A. 1993. The asiatic clam Corbicula fluminea (Müller, 1774) (Bivalvia: Corbiculidae) in Europe. American Malacological Bulletin 10:39-49.

Aroceno, R.; Chalar, G.; Fabián, D.; Deléon, L.; Brugnoli, E.; Silva, M.; Rodó, E; Machado, I.; Pacheco, J.; Castiglioni, R. \& Gabito, L. 2008. Distribución y descripción poblacional de moluscos invasores. Evaluación Ecológica de Cursos de Agua y Biomonitoreo. Uruguay, Informe final del Convenio DINAMA Facultad de Ciencias (Sec. Limnología). 17p.

Baker, A.; Bartlett, C.; Bunn, S.; Goudkamp, K.; Sheldon, F. \& Hughes, J. 2003. Cryptic species and morphological plasticity in long-lived bivalves (Unionoida: Hyriidae) from inland Australia. Molecular Ecology 12:2707-2717.

Beasley, C. R.; Tagliaro, C. H. \& Figueiredo, W. B. 2003. The occurrence of the Asian Clam, Corbicula fluminea in the lower Amazon basin. Acta Amazonica 33(2):317-324.

Belanger, S.; Farris, J.; Cherry, D. \& CAIrns, J. 1985. Sediments preference of the freshwater Asiatic clam, Corbicula fluminea. The Nautilus 99:66-73

Boltovskoy, D.; Correa, N.; Cataldo, D.; Stripeikis, J. \& Tudino, M. 1997. Environmental stress on Corbicula fluminea (Bivalvia) in the Paraná River Delta (Argentina): complex pollution-related disruption of population structures. Archiv für Hydrobiologie 138:483-507.

Britton, J. \& Morton, B. 1986. Polymorphism in Corbicula fluminea (Bivalvia: Corbiculoidea) from North America. Malacological Review 19:1-43.

Callil, C. \& Mansur, M. 2002. Corbiculidae in the Pantanal: history of invasion in southeast and central South America and biometrical data. Amazoniana 17:153-167.

Castillo, A.; Bortoluzzi, L. \& Oliveira, V. 2007. Distribuição e densidade populacional de Corbicula fluminea (Mueller, 1744) do arroio Imbaá, Rio Uruguai, Uruguaiana, Brasil. Biodiversidade Pampeana 5(1):25-29. Available at: <http://revistaseletronicas. pucrs.br/ojs/index.php/biodiversidadepampeana/article/ viewFile/2607/2020>. Accessed on: 20 January 2012.

Cazzaniga, N. J. 1997. Asiatic clam, Corbicula fluminea, reaching Patagonia (Argentina). Journal of Freshwater Ecology 12:629630.

Cazzaniga, N. J. \& Perez, C. 1999. Asiatic clam, Corbicula fluminea, in Northwestern Patagonia (Argentina). Journal of Freshwater Ecology 14(4):551-552.

Cherry, D.; Rodgers, J. \& Graney, R. 1980. Dynamics and control of the Asiatic clam in the New Rivers Virginia. Bulletin of the Virginia Water Resources Research Center 123:1-72.

Contardo-Jara, V.; Galanti, L. N. Amé M. V.; Monferrán, M. V. Wunderlin, D. \& Wiegand, C. 2009. Biotransformation and antioxidant enzymes of Limnoperna fortunei detect site impact in water-courses of Córdoba, Argentina. Ecotoxicology and Enviromental Safety 72:1871-1880.

CounTs, C. 1986. The zoogeography and history of invasion of the United States by Corbicula fluminea (Bivalvia: Corbiculidae). In: Prezant, R. S. ed. Proceedings of Second International Corbicula Symposium. American Malacological Bulletin (Special edition) 2:7-39.

DARrigran, G. 1991. Competencia entre dos especies de pelecipodos invasores Corbicula fluminea (Müller, 1774) y C. largillierti (Philippi, 1844) en el litoral argentino del estuario del Río de La Plata. Notas Científicas de la Segunda Reunión Argentina de Limnología 498:214-215.

1992a. Nuevos datos acerca de la distribución de las especies del género Corbicula (Bivalvia, Shapaeriacea) en el área del Río de La Plata, República Argentina. Notas del Museo de La Plata 21(210):143-148.

1992b. Variación temporal y espacial de la especie Corbicula megerler, 1811 (Bivalvia: Corbiculidae) en el estuario del Río de La Plata, República Argentina. Neotropica 38(99):59-63. 22.
2000. Invasive Freshwater Bivalves of the Neotropical Region. Dreissena 11:7-13

2002. Potential impact of filter-feeding invaders on temperate inland freshwater environments. Biological Invasions 4:145-156.

DARrigran, G. \& DamboreneA, C. 2005. La almeja de agua dulce Corbicula fluminea (Müller, 1774). In: Penchaszadeh, P. E. ed. Invasores. Invertebrados exóticos en el Río de La Plata y región marina aledaña. Buenos Aires, Eudeba. p. 133-177.

De La Hoz AristizÁBAL, M. 2008. Primer registro en Colombia de Corbicula fluminea (Mollusca: Bivalvia: Corbiculidae), una especie invasora. Boletín de Investigaciones Marinas y Costeras 37(1):195-200.

FAST, A. 1971. The invasion and distribution of the Asiatic clam (Corbicula manilensis) in the Southern California Reservoir. Bulletin Southern California Academy of Sciences 70:91-98.

FrançA, S; Suriani, A. \& Rocha, O. 2007. Composição das espécies de moluscos bentônicos nos reservatórios do baixo rio Tietê (São Paulo, Brasil) com uma avaliação do impacto causado pelas espécies exóticas invasoras. Revista Brasileira de Zoologia 24:41-51.

Horne, F. \& McIntosh, S. 1979. Factors influencing the distribution of mussels in the Blanco River of Central Texas. The Nautilus 94:119-133.

Hued, A. \& Bistoni, M. 2005. Development and validation of biotic index evaluation of environmental quality in the central region of Argentina. Hydrobiologia 543:279-298.

Ituarte, C. 1981. Primera noticia acerca de la introducción de pelecípodos asiáticos en el área rioplatense (Mollusca: Corbiculidae). Neotropica 27(77):79-83.

1994. Corbicula and Neocorbicula (Bivalvia: Corbiculidae) in the Paraná, Uruguay, and Río de La Plata basins. The Nautilus 107(4):129-135.

Krebs, C. J. 1999. Ecological Methodology. 2ed. Legendre, AddisionWesley Educational Publishers. 620p.

LeE, T.; Siripattawan, S.; ItUaRte, C. \& Foighle, D. 2005. Invasion of the clonal clams Corbicula lineages in the New World. American Malacological Bulletin 20:113-122.

Levin, S. A. 1992. The problem of pattern and scale in ecology. Ecology 73(6):1943-1967.

Maggioni, T.; Hued, A. C.; Monferrán, M. V.; Bonansea, R. I.; Galanti, L. N. \& AmÉ, M. V. 2012. Bioindicators and Biomarkers of Environmental Pollution in the Middle-Lower Basin of the Suquía River (Córdoba, Argentina). Archives of Environmental Contamination and Toxicology 63:337-353.

Mansur, M. \& Pereira, D. 2006. Bivalves límnicos da bacia do rio dos Sinos, Rio Grande do Sul, Brasil (Bivalvia, Unionoida, Veneroida e Mytiloida). Revista Brasileira de Zoologia 23(4):1123-1147.

Martins, D. S.; Veitenheimer-Mendes, I. L. \& Faccioni-Heuser, C. 2006. Aspectos morfológicos e de incubação em três espécies de Corbicula Mühlfeld, no lago Guaíba, Rio Grande do Sul, Brasil (Bivalvia, Corbiculidae). Biota Neotropica 6(2):1-11.

McMahon, R. 1983. Ecology of an invasive pest bivalve, Corbicula sp. In: Russell-Hunter, W. ed. The Mollusca Ecology. New York, Academic Press. p. 505-561.

2000. Invasive characteristics of fresh water bivalve Corbicula fluminea. In: Claudi, R. \& LECH, J. eds. Nonindigenous fresh water organisms; vectors, biology and impacts. Boca Raton, Lewis Punlishers. p. 315-343.

Monferrán, M. V.; Galanti, L. N.; Bonansea, R. I.; Amé, M. V. \& Wunderlin, D. A. 2011. Integrated survey of water pollution in the Suquía River basin (Córdoba, Argentina). Journal of Environmental Monitoring 13:398-409.

Morisita, M. 1962. I $\delta$ - Index, a measure of dispersion of individuals. Researches Population Ecology 4:1-7.

Morton, B. 1986. Corbicula in Asia an updated synthesis. American Malacological Bulletin 2:113-124.

Nimptsch, J.; Wunderlin, D. A.; Dollan, A. \& Pflugmacher, S. 2005. Antioxidant and biotransformation enzymes in Myriophyllum quitense as biomarkers of heavy metal exposure and eutrophication in Suquía River basin (Córdoba, Argentina). Chemosphere 61:147-157.

PARK, J.; LEE, J. \& KIM, W. 2002. A single mitochondrial lineage is shared by morphological and allozymatically distinct freshwater Corbicula clones. Molecular Cells 14(3):318-322.

Pfenninger, M.; Reinhardt, F. \& Streit, B. 2002. Evidence for 
cryptic hybridization between different evolutionary lineages of the invasive clam genus Corbicula (Veneroida, Bivalvia) Evolutionary Biology 15:818-829.

Renard, E.; Bachmann, V.; Cariou, M. \& Moreteau, J. 2000. Morphological and molecular differentiation of invasive freshwater species of the genus Corbicula (Bivalvia, Corbiculidae) suggest the presence of three taxa in French rivers. Molecular Ecology 9:2009-2016.

Rodrigues, J. C. A.; Pires-Junior, O. R.; Coutinho, M. F. M. \& Martins-Silva, M. J. 2007. First occurrence of the Asian Clam Corbicula fluminea (Bivalvia: Corbiculidae) in the Paranoá Lake, Brasília, Brazil. Brazilian Journal of Biology 67(4):789-790.

Rumi, A.; Gutiérrez, G. D.; NúÑEz, V. \& Darrigran, G. 2007. Malacología Latinoamericana. Moluscos de agua dulce de Argentina. Revista de Biología Tropical 56(1):77-111.

Sousa, R.; Freire, R.; Rufino, M.; Méndez, J.; GaSPar, M.; Antunes, C. \& Guilhermino, L. 2007. Genetic and shell morphological variability of the invasive bivalve Corbicula fluminea (Müller, 1774) in two Portuguese estuaries. Estuarine, Coastal and Shelf Science 74:166-174.
STRAYER, D. L. 2010. Alien species in fresh waters: ecological effects, interactions with other stressors, and prospects for the future. Freshwater Biology 55(1):152-174.

VÁzquez, J. B.; Lopez-Robles, A. \& Saez, M. P. 1979. Aguas. In: VÁzquez, J. B.; Miatello, R. A. \& Roque, M. ed. Geografía física de la provincia de Córdoba. Córdoba, Boldt, Banco de la Provincia de Córdoba. p. 139-211.

Veitenheimer-Mendes, I. 1981. Corbicula manilensis (Phillipi, 1844) molusco asiático, na bacia do Jacuí e do Guaíba, Rio Grande do Sul, Brasil (Bivalvia, Corbiculidae). Iheringia, Série Zoologia (60):63-74

Ward, J. L. \& Hodgson, J. R. 1997.The presence of the Asiatic clam, Corbicula sp., from Lake Superior. Journal of Freshwater Ecology 12:167-169.

Wittenberg, J. F. 1981. Animal Social Behaviour. Boston, Duxbury Press. 400p.

Wunderlin, D.; Amé, M.; Pesce, S.; Hued, A. \& Bistoni, M. 2001. Pattern recognition techniques for the evaluation of spatial and temporal variations in water quality. A case study: Suquía River Basin (Córdoba, Argentina). Water Research 35:2881-2894. 